\title{
The Effectiveness of Trichoderma spp. against Downy Mildew Disease of Corn
}

\author{
Joko Prasetyo $^{1}$, Sudiono ${ }^{1 *}$, Cipta Ginting ${ }^{1}$ and Yulia Citra Permatasari ${ }^{1}$ \\ ${ }^{1}$ Department of Plant Protection, Faculty of Agriculture, Lampung University, Postal Code 35144, \\ Bandar Lampung, Indonesia.
}

Authors' contributions

This work was carried out in collaboration among all authors. Authors JP and CG designed the study and wrote protocol. Author YCP performed statistical analysis and made some literature searches. Author Sudiono wrote the first draft of manuscript and managed the analyses of the study. All authors read, contributed and approved the final version of the manuscript.

Article Information

DOI: $10.9734 / A R R B / 2019 /$ v31i630068 Editor(s):

(1) Dr. Tunira Bhadauria, Professor, Department of Zoology, Feroze Gandhi Post Graduate College, Kanpur University, U. P.,

Reviewers:

(1) Dr. George Perry, Dean and Professor of Biology, University of Texas at San Antonio, USA.

(2) Douira Allal, University lbn Tofail, Morocco.

(3) Liamngee Kator, Benue State University, Nigeria.

(4) Seint San Aye, Yezin Agricultural University, Myanmar.

Complete Peer review History: http://www.sdiarticle3.com/review-history/49217

Original Research Article

Received 13 March 2019

Accepted 28 May 2019

Published 31 May 2019

\section{ABSTRACT}

Introduction: One of environmentally friendly method for controlling plant diseases is the use of Trichoderma spp. as a natural controlling agent.

Objectives: The objective of this research was to find out the effectiveness of Trichoderma spp. against downy mildew disease.

Methodology: This research was conducted in the Plant Pest and Disease Laboratory in the Plant Protection Department of Faculty of Agriculture in Lampung University. This research used completely randomized design consisting without treatment (0), Trichoderma spp. Gading Rejo Region (GDR) isolate (1) Trichoderma spp. Nusantara Tropical Farm (NTF) isolate (2), and Trichoderma spp. Trimurjo (TRJ) isolate (3) treatments which were applied to the plant growing points as fungicide $(B)$ and as inducer of plant resistance to be applied in the plant roots $(P)$.

Results: The research results showed that the Trichoderma spp. treatments could reduce the disease occurrence at 4 and 5 days after inoculation, but they could not reduce the disease severity and improve stover dry weight of corn plant. 
Conclusion: The Trichoderma spp. Treatment as biofungicide and plant resistance inducer are effective against the incubation period and suppress the disease occurrence of downy mildew disease significantly at the early course of the disease.

Keywords: Biofungicide; downy mildew; plant resistance inducer; Trichoderma spp.

\section{INTRODUCTION}

Corn (Zea mays L.) is one of harvest crops which has an important economy value in Indonesia. The corn seeds contain of carbohydrate, protein, fat, vitamin, and important minerals. Lampung province is one of corn production center areas in Indonesia, and the areas are distributed in some districts like South Lampung, East Lampung, and Middle Lampung, Lampung Province Indonesia.

The dry peeled corn production in Lampung Province in 2012-2015 decreased from $1,760,275$ ton in $2012 ; 1,760,278$ ton in $2013 ; 1,719,386$ ton in 2014 ; into $1,502,800$ ton in 2015. Decreasing trend of corn production is related to problems in the existing corn culturing such as pest and disease attacks, and one of important disease in corn plant is downy mildew disease [1].

The downy mildew disease is caused by Peronosclerospora spp. fungi. The potential of corn production cannot be obtained if the corn is infected by the downy mildew disease This disease in the beginning only occurred in some corn plantation areas in Indonesia, but then it spread into some provinces [2]. This downy mildew reduces up to $90 \%$ of corn production, especially when the pathogen infection occurs at the early of vegetative growth course [3].

The downy mildew disease can be controlled by using resistant varieties, environment sanitation, plant rotation, simultaneous planting time arrangement, and treatment of seeds by using synthetic fungicide (active ingredients of metalaxyl) [4]. Continuous use of metalaxyl in long term can cause resistance to the cause of downy mildew disease [5]. The alternative for controlling this disease is by using natural controlling agent which is environmentally friendly such as Trichoderma spp. fungi which can be used to control downy mildew disease by functioning as biofungicide and improving plant resistance to pathogen by inducing corn plant resistance.

The most common known inhibiting type and working mechanism of Trichoderma spp. are micro-parasitism, space and nutrition competition, the toxin production of Trichodermin, Gliotoxin, and Gliovirinto degrade pathogenic cells so that they cannot develop, the plant resistance induction, sprouting metabolism stimulation and additional mechanism related to plant resistance against the disease [6]. The target-specific Trichoderma spp. controlling mechanism which is colonizing rhizosphere immediately andprotecting roots from pathogenic fungal attack, accelerating the plant growth and improving plant production result, become the superiorities as a natural controlling agent.Trichoderma spp. is easy to propagate massively and easy to store in long term [7]. Based on these elaborations, a research was required to test Trichoderma spp. fungi effectiveness as biofungicide and inducer of corn (Zea mays L.) plant resistance against downy mildew disease.

The objective of this research was to find out the effectiveness of Trichoderma spp. against downy mildew disease.

\section{MATERIALS AND METHODS}

This research was conducted from May to July 2018, in the Plant Pest and Disease Laboratory of Plant Protection Department of Faculty of Agriculture in Lampung University. This research used a completely randomized design with 16 treatments and repeated 3 times with a total of 48 units of trials. The treatments were without treatment (0), Trichoderma spp. Gading Rejo Region (GDR) isolate (1) Trichoderma spp. Nusantara Tropical Farm (NTF) isolate (2), and Trichoderma spp. Trimurjo (TRJ) isolate (3) which were applied to the plant growing points as fungicide (B) and as inducer of plant resistance to be applied in the plant roots $(P)$.

Obtained data were tested for homogeneity by using Bartlett test and Tukey test to test additions. When the assumption was satisfied, data were analyzed by using analysis of variance and middle value comparison between treatments was tested by using Scheffé test in $5 \%$ trust level. In Scheffé test, treatments were grouped as they are shown in Table 1 and Table 2. 
Table 1. Group/structure of Trichoderma spp. treatments as biofungicide and corn plant resistance inducer against downy mildew disease at Scheffé test

\begin{tabular}{|c|c|c|}
\hline Group/ structure of treatments & Description & Symbol \\
\hline A & Control & BOP0 \\
\hline B & $\begin{array}{l}\text { Trichoderma spp. isolate treatments at } \\
\text { growth points }\end{array}$ & B1P0, B2P0, B3P0 \\
\hline C & $\begin{array}{l}\text { Trichoderma spp. isolate treatments at } \\
\text { roots }\end{array}$ & B0P1, B0P2, B0P3 \\
\hline D & $\begin{array}{l}\text { Trichoderma spp. isolate similar } \\
\text { treatments at growth points and roots }\end{array}$ & B1P1, B2P2, B3P3 \\
\hline$E$ & $\begin{array}{l}\text { Trichoderma spp. isolate different } \\
\text { treatments at growth points and roots }\end{array}$ & $\begin{array}{l}\text { B1P2, B1P3, B2P1, } \\
\text { B2P3, B3P1, B3P2 }\end{array}$ \\
\hline
\end{tabular}

Table 2. The main contrast of Trichoderma spp. treatments as biofungicide and corn plant resistance inducer against downy mildew at Scheffé test

\begin{tabular}{|c|c|c|}
\hline Comparison & Description & Symbol \\
\hline$A$ vs $B, C, D, E$ & $\begin{array}{l}\text { Control versus all treatments of } \\
\text { Trichoderma spp. }\end{array}$ & $\begin{array}{l}\text { B0P0 vs } \\
\text { B0P1, B0P2, B0P3, B1P0, B1P1, B1P2, } \\
\text { B2P3, B2P0, B2P1, B2P2, B2P3, B3P0, } \\
\text { B3P1, B3P2, B3P3. }\end{array}$ \\
\hline$B, C$ vs $D, E$ & $\begin{array}{l}\text { Trichoderma spp. treatments at one of } \\
\text { plant parts (either growth points or } \\
\text { roots only) versus both of them (growth } \\
\text { points and roots) }\end{array}$ & $\begin{array}{l}\text { B1P0, B2P0, B3P0, B0P1, B0P2, B0P3 } \\
\text { vs } \\
\text { B1P1, B2P2, B3P3, B1P2, B1P3, B2P1, } \\
\text { B2P3, B3P1, B3P2 }\end{array}$ \\
\hline B vs $C$ & $\begin{array}{l}\text { Trichoderma spp. treatments at growth } \\
\text { points versus roots. }\end{array}$ & $\begin{array}{l}\text { B1P0, B2P0, B3P0 vs } \\
\text { B0P1, B0P2, B0P3 }\end{array}$ \\
\hline$D$ vs $E$ & $\begin{array}{l}\text { Trichoderma spp. treatments at both } \\
\text { plant parts (growth points and roots); } \\
\text { the same isolate versus different } \\
\text { isolate. }\end{array}$ & $\begin{array}{l}\mathrm{B} 1 \mathrm{P} 1, \mathrm{~B} 2 \mathrm{P} 2, \mathrm{~B} 3 \mathrm{P} 3 \text { vs } \\
\mathrm{B} 1 \mathrm{P} 2, \mathrm{~B} 1 \mathrm{P} 3, \mathrm{~B} 2 \mathrm{P} 1, \mathrm{~B} 2 \mathrm{P} 3, \mathrm{~B} 3 \mathrm{P} 1, \mathrm{~B} 3 \mathrm{P} 2\end{array}$ \\
\hline
\end{tabular}

\subsection{Incubation Time (Day)}

The incubation time is the required by the plant from inoculation until early plant sicknesssymptom appears. Observation was done every day until early downy mildew disease symptom appeared. Isolate Trichoderma spp. isolated from maize plantations namely Gading Rejo Region (GDR), Nusantra Tropical Farm (NTF_ and Trimurjo (TRJ). Inoculation of the disease is carried out in two ways, namely naturally and artificially. Inoculation in maize plants is carried out by laying dried corn plants and corn leaf blight in pots around the test plants in the experiment plot.

\subsection{Disease Occurrence (\%)}

Disease occurrence is the numbers of units of sick plants compared to all observed units. Unit here could be parts of a plant, a whole individual, or a clump of plant. The disease occurrence can be estimated by using a formula [8]:

$$
\mathrm{TP}=\frac{n}{N} \times 100 \%
$$

Description:

$$
\begin{array}{ll}
\text { TP } & =\text { Disease occurrence (\%) } \\
n & =\text { unit of sick plant } \\
N & =\text { observed unit of plant }
\end{array}
$$




\subsection{Disease Severity (\%)}

Disease severity is defined as area or volume of sick plant tissue compared to all area or volume. Disease score and scaleare used to measure the plant disease severity.A disease is given a score according to the occurring severity level. The more severe the disease, the higher the score and the lower the score, the lower the severity. Disease score or scale and formula of disease severity was modified based on [8] reference, which is expressed as follows:

$$
\mathrm{PP}=\sum \frac{(n \times v)}{N \times V} \times 100 \%
$$

Description:

PP : Disease severity (\%)

$\mathrm{n}:$ numbers of leaf with certain score

$v$ : Numeric value for each category of disease attack

$\mathrm{N}$ : Observed numbers of leaf(sample)

$\mathrm{V}$ : Highest score or scale

\subsection{Stover Dry Weight (g)}

The plant was cut at the part between stem and root. The stover was then cut and dried with sunrays for 4 days. The dried stover was entered into envelops to be entered into oven with $80^{\circ} \mathrm{C}$ temperature for 7 days until the stover weight was constant.
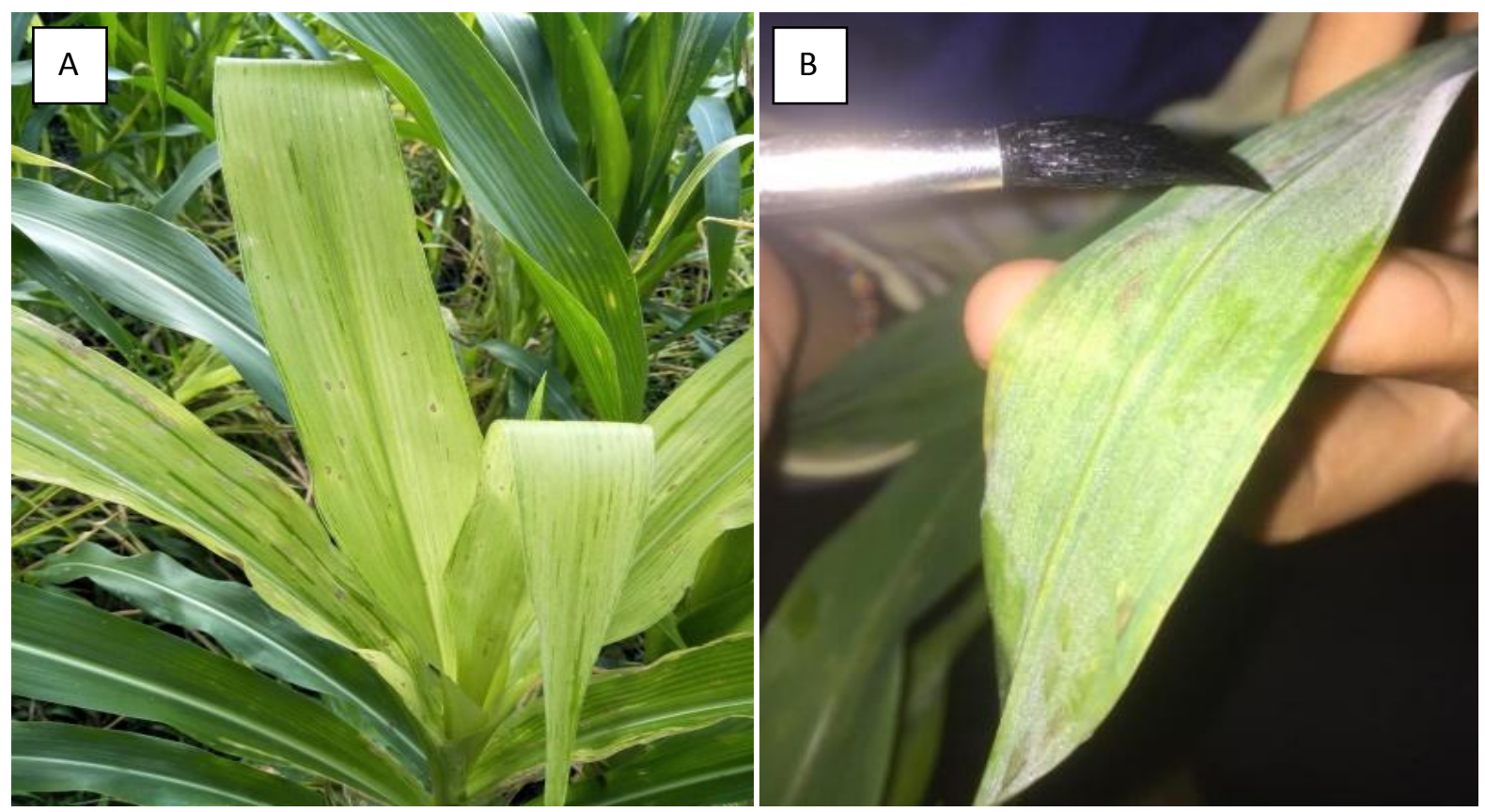

Fig. 1. The symptom of downy mildew disease: (A) leaf chlorosis, (B) conidia layer fungi with white color like powder on leaf surface

\section{RESULTS AND DISCUSSION}

\subsection{Symptoms of Corn Downy Mildew Disease}

The downy mildew disease symptom was started with leaf with chlorosis or whitey color extending parallel to the leaf bone (Fig. 1A). This symptom appeared most early at 4 days after inoculation of Peronosclerospora sp. fungi. There was conidia layer of fungi with white color like powder on leaf surface (Fig. 1B).

\subsection{Incubation Time of Downy Mildew Disease}

The Trichoderma spp. fungi treatment result as biofungicide and plant resistance inducer affected in extending the downy mildew incubation time (Table 3).

\subsection{Occurrence of Downy Mildew Disease}

The occurrence of downy mildew disease is the percentage of sick plant compared to all observed plants in a certain area. The Trichoderma spp. fungi treatment as biofungicide and plant resistance inducer affected in reducing the downy mildew disease occurrence at 4 and 5 days after inoculation (DAI) (Table 4). 
Table 3. The downy mildew disease incubation time (day) with Trichoderma spp. treatment as biofungicide and plant resistance inducer

\begin{tabular}{|c|c|c|c|c|c|}
\hline No & Treatment group & Description & Incubation time & F-hit scheffe & F-table \\
\hline \multirow[t]{3}{*}{1} & A & Control & 4,0 & 6,84 & 2,01 \\
\hline & & versus & vs & & \\
\hline & $\mathrm{B}, \mathrm{C}, \mathrm{D}, \mathrm{E}$ & all Trichoderma spp. treatments & 4,6 & & \\
\hline \multirow[t]{3}{*}{2} & $\mathrm{~B}, \mathrm{C}$ & \multirow{3}{*}{$\begin{array}{l}\text { Trichoderma spp. treatment at either part of plant } \\
\text { (growth point or root only) } \\
\text { versus } \\
\text { Trichoderma spp. treatment at both parts of plant } \\
\text { (growth point and root) }\end{array}$} & 4,2 & 30,14 & 2,01 \\
\hline & vs & & vs & & \\
\hline & $D, E$ & & 4,9 & & \\
\hline \multirow[t]{3}{*}{3} & $\mathrm{~B}$ vs $\mathrm{C}$ & Trichoderma spp. treatment at growth point & 4,1 & $1,62^{\mathrm{tn}}$ & 2,01 \\
\hline & & versus & vs & & \\
\hline & & Trichoderma spp. treatment at root & 4,3 & & \\
\hline \multirow[t]{3}{*}{4} & $\mathrm{D}$ vs $\mathrm{E}$ & Trichoderma spp. treatment at both growth points & 4,9 & $0,10^{\text {tn }}$ & 2,01 \\
\hline & & and roots with same isolate & vs & & \\
\hline & & $\begin{array}{l}\text { versus } \\
\text { Trichoderma spp. treatment at both growth points } \\
\text { and roots with different isolate }\end{array}$ & 4,9 & & \\
\hline
\end{tabular}


Table 4. Downy mildew disease occurrence (\%) with Trichoderma spp. treatment as biofungicide and resistance inducer of corn plant

\begin{tabular}{|c|c|c|c|c|c|c|c|}
\hline \multirow[t]{2}{*}{ No } & \multirow[t]{2}{*}{ Treatment Group } & \multirow[t]{2}{*}{ Description } & \multicolumn{2}{|l|}{ Disease occurrence (\%) } & \multicolumn{2}{|c|}{ F-hit Scheffe } & \multirow[t]{2}{*}{ F-tabel } \\
\hline & & & 4 DAl & 5 DAl & 4 DAl & 5 DAl & \\
\hline 1. & $\begin{array}{l}\text { A } \\
\text { vs } \\
B, C, D, E\end{array}$ & $\begin{array}{l}\text { Control } \\
\text { versus } \\
\text { all Trichoderma spp. } \\
\text { treatments }\end{array}$ & $33,27(1,72) v s 12,35(1,44)$ & $61,87(7,85)$ vs $45,98(6,65)$ & 7,40 & 2,59 & 2,01 \\
\hline 2. & $\begin{array}{l}\text { B, C } \\
\text { vs } \\
D, E\end{array}$ & $\begin{array}{l}\text { Trichoderma spp. } \\
\text { treatment at either part } \\
\text { of plant (growth point } \\
\text { or root only) } \\
\text { versus } \\
\text { Trichoderma spp. } \\
\text { treatment at both parts } \\
\text { of plant (growth point } \\
\text { and root) }\end{array}$ & $26,14(1,62) v s 3,16(1,32)$ & $62,66(7,89) v s 34,86(5,82)$ & 33,60 & 29,90 & 2,01 \\
\hline 3. & B vs C & $\begin{array}{l}\text { Trichoderma spp. } \\
\text { treatment at growth } \\
\text { point } \\
\text { versus } \\
\text { Trichoderma spp. } \\
\text { treatment at root }\end{array}$ & $26,92(1,66)$ vs29,72 $(1,63)$ & $65,04(8,03)$ vs60,28 $(7,76)$ & $0,99^{\mathrm{tn}}$ & $0,21^{\text {tn }}$ & 2,01 \\
\hline 4. & D vs $E$ & $\begin{array}{l}\text { Trichoderma spp. } \\
\text { treatment at both } \\
\text { growth points and } \\
\text { roots with same isolate } \\
\text { versus } \\
\text { Trichoderma spp. } \\
\text { treatment at both } \\
\text { growth points and } \\
\text { roots with different } \\
\text { isolate }\end{array}$ & $1,58(1,30) v s 3,96(1,33)$ & $\begin{array}{l}38,03(6,08) \\
\text { vs } \\
33,27(5,68)\end{array}$ & $0,17^{\mathrm{tn}}$ & $0,61^{\text {tn }}$ & 2,01 \\
\hline
\end{tabular}

Note: $D A I=$ day after inoculation; ${ }^{*}=$ significant, $t n=$ not significant, number in parenthesis is the transformation result of $\sqrt{ }(x+0,5)$ 


\subsection{Downy Mildew Disease Severity Level}

The result of analysis of variance of all Trichoderma spp. fungi treatments as biofungicide and plant resistance inducer showed that they were not able to suppress the downy mildew disease severity level at 7, 14, and 21 days after inoculation (DAI) (Table 5). The middle value separation test with Scheffé test at $5 \%$ was not conducted because $F_{\text {count }}$ value at the analysis of variance was lower than $F_{\text {table }}$ value (not significant).

\subsection{Stover Dry Weight}

The result of analysis of variance of all Trichoderma spp. fungi treatments as biofungicide and plant resistance inducer showed that they were not able to improve the stover dry weight of corn plant with downy mildew disease (Table 6). The middle value separation test with Scheffe test at 5\% was not conducted because $F_{\text {count }}$ value at the analysis of variance was lower than $F_{\text {table }}$ value (not significant).

The research results showed that the early downy mildew disease symptom appeared at 4 days after inoculation or 14 days after planting. The symptom was leaf with chlorosis or whitey color extending in parallel along the leaf bone (Fig. 1A). There was fungal spore layer with white color like powder on the leaf surface (Fig. $1 \mathrm{~B})$, and these fungi were very visible in the morning. The symptom was systemic because it attacked growth points and spread to all plant parts. This is in line with [9] who suggests that the downy mildew disease is able to cause spreading systemic symptom extending to all plant parts or able to cause local symptom. The systemic symptom only occurs when fungus in the infected leaf can reach growing points so that they will infect all leaf formed by the growth points. At 2-3 weeks plant, the stem growth is inhibited, the color goes into yellowish, and there are fungal conidium layers with white color at underside of the leaf.

The Trichoderma spp. as biofungicide and plant resistance inducer was able to extend incubation time of downy mildew disease (Table 3) and reduced disease occurrence at 4 and 5 days after inoculation (Table 4). The Trichoderma spp. treatment in this research could only reduce the disease occurrence at 4 and 5 days after inoculation. The research result of Sutama et al [10] and [11] suggests that the Trichoderma spp. application could reduce the disease occurrence of downy mildew disease at hybrid corn NK22 only at 33 and 40 days after planting. This might be because the severe pathogen attacks level from natural pathogen inoculation caused by climate factor such as air humidity and temperature. This factor was strengthened by the continuous rainy climate condition when inoculation was conducted.

Trichoderma spp. is able to serve as a biofungicide in extending the incubation time and to reduce disease occurrence of downy mildew by inhibiting the Peronosclerospora sp. fungus growth that cause downy mildew disease by competing aggressively or occupying unoccupied spaces. The suggests that the Trichoderma spp. as an active biofungicide fungal agent has microparasite nature, which inhibits other fungal growths by parasitism mechanism. The occurring mechanism is that the Trichoderma spp. fungal growth runs twice faster so that they shall coil surrounding pathogen fungal hyphae. Along with coiling and surrounding these hyphae, enzyme capable of modifying cellular walls of pathogenic fungal hyphae is released [12].

Table 5. The analysis of variance of downy mildew disease severity level with Trichoderma spp. treatment as biofungicide and corn plant resistance inducer

\begin{tabular}{|c|c|c|c|c|}
\hline \multirow{2}{*}{ Analysis of Variance } & \multicolumn{3}{|c|}{ F-count } & \multirow[t]{2}{*}{ F-table } \\
\hline & 7 DAI & 14 DAl & 21 DAl & \\
\hline Treatment & $0,73^{\mathrm{tn}}$ & $0,54^{\mathrm{tn}}$ & $0,84^{\mathrm{tn}}$ & 2,01 \\
\hline
\end{tabular}

Table 6. The analysis of variance of corn plant stover treated with Trichoderma spp. as biofungicide and corn plant resistance inducer against downy mildew disease

\begin{tabular}{lll}
\hline Analysis of Variance & F-count & F-table \\
\hline Treatment & $1,21^{\text {tn }}$ & 2,01 \\
\hline & Note: ${ }^{*}=$ significant, $t n=$ not significant &
\end{tabular}


Trichoderma spp. serving as inducer of plant resistance is also proven to be able to induce actively plant resistance gens from being passive into active. The Trichoderma spp. fungus can improve plant resistance by activating resistance gens in the plant. The Trichoderma spp. fungus applied to corn plant roots can trigger peroxide enzyme activity serving to strengthen cellular walls against enzyme degradation produced by pathogen through formation of structural protein in cellular walls. Peroxide is an enzyme serves as catalysator at final process of lignin biosynthesis and hydrogen peroxide processes [13].

This result is strengthened with [14] who states that induced resistance commonly is systemic, because resistance ability is improved not only in the infected plant parts, but also in uninfected plant parts. Some Trichoderma spp. strains have potentials as influencers that produce systemic resistance reactions in the plant. One of produced resistance reactions is improvement of chitinase enzyme in the plant tissues. Therefore, the Trichodermaspp. fungal isolate can reduce the disease occurrence of downy mildew disease at corn plant through mechanism of plant resistance induction.

Induced systemic resistance can be made as an alternative to obtain genetic diversity, especially the plant resistance character against a disease. The systemic resistance induction is a process to stimulate resistance of host plant without introduction of new genes. Systemic resistance induction causes a physiological condition that regulates to activate resistance system and stimulate natural resistance mechanism owned by the host by applying external induction materials. External inducer materials can be biological, chemical, and physical agents [15].

Plant resistance improvement by induction can be done by Systemic Acquired Resistance (SAR) process or Induced Systemic Resistance (ISR) that involve varying types of genes, enzymes, and proteins. The plant resistance improvement by SAR occurs after a pathogen infection locally at the plant, and then the infected plant activates genes serving for resistance (pathogenic related genes) that produce chemical compounds for plant defense, salicylate acid and PR-protein group like peroxides. When the plant has been induced for its resistance, and then being infected again by other pathogens, the plant will be able to defend itself against undeveloped or localized pathogen infection because the plant cells around infected site die. The cell death in this process is commonly referred to as hypersensitive reaction. Meanwhile, the trigger of resistance by SAR occurs not because of pathogenic infection, but by Trichoderma spp. infection. The plant responses the Trichoderma spp. infection, and then the plant produces plant defense compounds such as jasmonic acid and ethylene compounds [16].

Trichoderma spp. can also stimulate the formation of varying compounds that are able to induce plant resistance both locally and systematically against pathogens [17]. In inducing plant resistance, Trichoderma spp. had been reported to be able to activate jasmonic acid and ethylene compound signal paths [18]. The potential of some Trichoderma spp. strains in inducing plant resistance has been widely reported. Trichoderma harzianum T39 induces bean plant resistance [19] and other Trichoderma spp. are able to induce resistance for varying plants against different diseases.

Trichoderma spp. serving as biofungicide and plant resistance inducer ins not influential to reduce disease severity and to improve plant stover dry weight. It is suspected because unsuccessful efficacy of Trichoderma spp. formulation as soil infectious fungal controller is determined by some factors including soil humidity, types of soils, method and application [20]. Natural agent before being introduced into soil should be propagated massively in organic materials according to growth and development so that it will make adaptation with a new environment after being introduced into the soil. The antagonist fungal growth is very depending on input of energy and nutrition that are commonly available in the planting media. Antagonist fungus obtains energy and nutrition from organic material decomposition in the soil and uses it for their activities and propagation of the population [21].

According to [22], to obtain effective antagonist fungus in controlling plant disease, the antagonist fungus must have good quality. The antagonist fungus quality is determined by numbers of formed propagules (conidia) and percentage of fungal propagules growth. To obtain good quality fungus, a supporting media (Potato Dextrose Agar) is required to improve numbers of propagule and its growth, one of them is rice grain organic material. A research done by [23] indicates that the Trichoderma spp. propagation in rice bran media is better. It is 
because more nutrition content in rice bran media and it is easier to degrade by Trichoderma spp. fungus, so that the numbers of Trichoderma spp. spores are much more compared to other propagation media. According to [24], the rice bran nutrition content is very suitable for Trichoderma spp. fungal sporulation and higher sporulation process will produce more numbers of spores, and vice versa.

\section{CONCLUSION}

The conclusion of this research is that the Trichoderma spp. treatment as biofungicide and plant resistance inducer are effective against the incubation period and suppress the disease occurrence of downy mildew disease significantly at the early course of the disease.

\section{ACKNOWLEDGEMENTS}

The authors would like to thank Prof. Dr. FX Soesilo (Lecturer of Entomology and Statistics in Lampung University) for provided assistance statistical analysis.

\section{COMPETING INTERESTS}

Authors have declared that no competing interests exist

\section{REFERENCES}

1. Central Bureau of Statistic. Laporan tahunan balai proteksi tanaman pangan dan hortikultura. Provinsi Lampung; 2016.

2. Lukman R, Afifuddin A, Thomas L. Tracing the signature of peronosclerospora maydis in maize seed. Australia. Plant Pathology. 2016;45(1):73-82.

3. Hoerussalam A, Purwanto, Kheruni A. Induced resistance of downy mildew on maize (zea mays L.) By seed treatment and its inheritance in s1 generation. Jurnal Ilmu Pertanian. 2013;16(2):42-59.

4. Korlina E, Amir AM. Efektivitas jenis fungisida terhadap penyakit bulai (peronosclerospora maydis) pada jagung. Prosiding Seminar Nasional Serealia. Jakarta; 2015.

ISBN: 978-9798940-40-8.

5. Burhanuddin. Fungisida Metalaksil Tidak Efektif Menekan Penyakit Bulai di Kalimantan Barat dan Alternatif Pengendaliannya. Prosiding Seminar Nasional Serealia. Maros; 2009. ISBN: 978-9798940-27-9.
6. Hoerussalam A, Purwanto, Kheruni A. Induced resistance of downy mildew on maize (zea mays L.) By seed treatment and its inheritance in s1 generation. Jurnal Ilmu Pertanian. 2013;16(2):42-59.

7. Purwantisari S, Hastuti RB. Uji antagonisme jamur patogen Phytophthora infestans penyebab penyakit busuk daun dan umbi tanaman kentang dengan menggunakan Trichoderma spp. Isolat lokal. BIOMA. 2009;11(1):24-32.

8. Ginting, C. Ilmu penyakit tumbuhan konsep dan Aplikasi. lembaga penelitian universitas Lampung. Bandar Lampung; 2013.

9. Semangun H. Penyakit-Penyakit Tanaman Pangan di Indonesia. Gajah Mada University. Yogyakarta; 2004.

10. Hoerussalam A, Purwanto, Kheruni A. Induced resistance of downy mildew on maize (zea mays L.) By seed treatment and its inheritance in s1 generation. Jurnal Ilmu Pertanian. 2013;16(2):42-59.

11. Purwantisari $\mathrm{S}$, Hastuti RB Uji antagonisme jamur patogen Phytophthora infestans penyebab penyakit busuk daun dan umbi tanaman kentang dengan menggunakan Trichoderma spp. Isolat Lokal. BIOMA. 2009;11(1):24-32.

12. Yulia $\mathrm{E}$, Istifadah $\mathrm{N}$, Widiantini $\mathrm{F}$, Utami HS. Antagonisms of Trichoderma spp. against Rigidoporus lignosus (Klotzsch) Imazeki and supression of white root disease on rubber plant. Jurnal Agrikultura. 2017;28(1):47-55.

13. Oanh KL, Vichai K, Chainarong R, Sirikul W. Influence of biotic and chemical plant inducers on resistance of chilli to anthracnose. Jurnal Departement of Plant Pathology. 2006;40(1):39-48.

14. Darwis HS. Induksi resistensi konidia Trichoderma koningii terhadap Phytophthora nicotianae pada beberapa varietas tembakau Deli. Jurnal Agrium. 2010;16(2):46-56.

15. Agrios GN. Plant Pathology $5^{\text {th }}$ Ed. Elsevier Academic Press. United States; 2005.

16. Pieterse CMJ, Leon-Reyes A, Van der Ent S, Van Wees S. C M. Networking by smallmolecule hormones in plant immunity. Nature Chemical Biology. 2009;5(5):308316.

17. Harman GE, Howell CR, Viterbo A. Trichoderma species opportunistic, avirulent plant symbionts. Nat. Rev. Microbiology. 2004;2(1):43-56. 
18. Saksirirat $\mathrm{W}$, Chareerak $\mathrm{P}$, Bunyatrachata W. Induced systemic resistance of bio control fungus, Trichoderma spp. against bacterial and gray leaf spot in tomatoes. As. J. Food Ag-Ind. 2009;99-104.

19. De Meyer G, Bigirimana J, Elad Y. Höfte, $M$. Induced systemic resistance in Trichoderma harzianum T39 biocontrol of Botrytis cinerea. European Journal of Plant Pathology. 1998;104(3):279-286.

20. Faishol F, Ivayani, Sudihartha N, Prasetyo J. The Effectiveness of some Trichoderma $\mathrm{sp}$. isolates on disease incidence of downy mildew caused by Peronosclerospora maydis and growth of corn (Zea mays). Jurnal Penelitian Pertanian Terapan. 2018; 18(1):39-45.

21. Darwis HS. Induksi resistensi konidia trichoderma koningii terhadap phytophthora nicotianae pada beberapa varietas tembakau Deli. Jurnal Agrium. 2010;16(2):46-56.

22. Chatri M, Handayani D, Septiani J. Influence of media (mixture of rice and sugar cane) on Trichoderma harzianum growth and its resistance to Fusarium Oxysporum by in vitro. Bioscience. 2018; 2(1):50-60.

23. Ginting C, Maryono T. The efficacy of Trichoderma harzianum with various organic matter in controling foot rot of black pepper. Jurnal Hama dan Penyakit Tumbuhan Tropika. 2011;11(2):147-156.

24. Gusnawaty HS, Taufik M, Banda LOS, Asis A. Effectiveness of several media for propagation biological agent Trichoderma sp. Jurnal Hama dan Penyakit Tumbuhan Tropika. 2017;17(1):84-95.

(C) 2019 Prasetyo et al.; This is an Open Access article distributed under the terms of the Creative Commons Attribution License (http://creativecommons.org/licenses/by/4.0), which permits unrestricted use, distribution, and reproduction in any medium, provided the original work is properly cited.

Peer-review history:

The peer review history for this paper can be accessed here: http://www.sdiarticle3.com/review-history/49217 